\title{
Efek Strategi Pembelajaran Scaffolding terhadap Kemampuan Pemecahan Masalah Matematis berdasarkan Kemampuan Awal Matematis Siswa
}

\author{
Desi Mardaleni, Noviarni*. Erdawati Nurdin \\ Jurusan Pendidikan Matematika, Universitas Islam Negeri Sultan Syarif Kasim Riau \\ *e-mail: noviarni@uin-suska.ac.id
}

\begin{abstract}
ABSTRAK: Kemampuan pemecahan masalah merupakan salah satu kecakapan yang diperlukan siswa untuk menghadapi tantangan global. Perlu dilakukan penelitian untuk memfasilitasi kemampuan pemecahan maslah matematis siswa. Penelitian ini bertujuan untuk menyelidiki ada tidaknya perbedaan kemampuan pemecahan masalah matematis antara siswa yang mengikuti strategi pembelajaran scaffolding dengan siswa yang memperoleh pembelajaran konvensional. berdasarkan kemampuan awal matematis siswa. Penelitian ini merupakan penelitian quasi eksperimen. Desain yang digunakan adalah nonequivalent posttest-only control group design. Populasi dalam penelitian ini adalah seluruh siswa kelas VIII SMP Negeri 3 Tualang Perawang. Sampel penelitian ini dipilih dengan menggunakan teknik cluster random sampling. Instrumen pengumpulan data yang digunakan adalah tes dan observasi. Data yang diperoleh dianalisis menggunakan uji anova dua arah (two way anova). Berdasarkan hasil analisis data dapat disimpulkan bahwa: 1) Terdapat perbedaan kemampuan pemecahan masalah matematis siswa yang mengikuti pembelajaran scaffolding dengan siswa yang menggunakan pembelajaran konvensional; 2) Terdapat perbedaan kemampuan pemecahan masalah matematis antara siswa dengan kemampuan awal tinggi, sedang dan rendah; 3) Tidak terdapat interaksi strategi pembelajaran scaffolding dan kemampuan awal matematika terhadap kemampuan pemecahan masalah matematis siswa. Strategi pembelajaran scaffolding dapat dijadikan salah satu alternatif strategi pembelajaran pada mata pelajaran matematika.
\end{abstract}

Kata kunci: Kemampuan Awal Matematika, Kemampuan Pemecahan Masalah Matematis, Scaffolding, Strategi Pembelajaran, Penelitian Kuasi Eksperimen.

\section{PENDAHULUAN}

Matematika dinilai sebagai salah satu mata pelajaran yang memegang peranan penting dalam membentuk siswa menjadi berkualitas, karena matematika merupakan suatu sarana berpikir untuk mengkaji sesuatu secara logis dan sistematik. Matematika juga merupakan sarana dalam mengembangkan cara berfikir, itulah kenapa matematika sangat diperlukan untuk kehidupan sehari-hari. Besarnya peranan matematika tersebut menuntut siswa harus mampu menguasai pelajaran matematika, sebab matematika dapat digunakan sebagai sarana untuk memecahkan masalah kehidupan sehari-hari.

Pemecahan masalah akan menjadi hal yang sangat menentukan keberhasilan pembelajaran matematika, sehingga pengintegrasian pemecahan masalah selama pembelajaran berlangsung hendaknya menjadi suatu keharusan. Peraturan Menteri Pendidikan dan Kebudayaan No 21 tahun 2016 tentang standar isi pendidikan dasar dan menengah mengungkapkan bahwa salah satu kompetensi pembelajaran matematika adalah menunjukkan sikap logis, kritis, analitis, cermat dan teliti, bertanggung jawab, responsif, dan tidak mudah menyerah dalam memecahkan masalah Berdasarkan kompetensi pembelajaran matematika jelas bahwa kemampuan pemecahan masalah matematis merupakan kemampuan yang harus dimiliki oleh setiap siswa.

NCTM mendefinisikan kata problem solving atau pemecahan masalah sebagai tugas matematika berupa tantangan intelektual untuk meningkatkan pemahaman dan perkembnagan matematika siswa (NCTM, 2000). Ditjen Pendidikan Dasar dan Menengah menegaskan bahwa 
kemampuan pemecahan masalah adalah salah satu kecakapan yang dibutuhkan siswa dalam menghadapi tantangan global di masa yang akan datang (Dit.PSMA, 2017). Pernyataan menunjukkan bahwa kemampuan pemecahan masalah merupakan yang wajib dimiliki oleh setiap siswa sebagai bekal dalam menghadapi era globalisasi. Namun, pada kenyataannya kemampuan pemecahan masalah matematis siswa Indonesia masih tergolong lemah. Hal ini dapat dilihat dari berbagai survei internasional yang mengukur kemampuan pemecahan masalah matematis siswa di dunia. Berdasarkan survei PISA 2015, rata-rata kemampuan matematika siswa Indonesia yang berumur 15 tahun hanya 386 poin, jauh di bawah rata-rata skor peserta survei, yaitu 490 (OECD, 2018). Rendahnya kemampuan matematis siswa ini seyogyanya mendapat perhatian khusus, terutama dalam proses pembelajaran. Salah satu langkah yang dapat dilakukan adalah dengan menerapkan strategi pembelajaran yang mampu memfasilitasi kemampuan pemecahan masalah matematis siswa.

Thambychik dan Meerah (2010) menyatakan bahwa banyak siswa kesulitan memahami masalah, membuat keputusan apa yang harus mereka lakukan, serta membuat koneksi dari masalah tersebut. Dalam proses pemecahan masalah, sebagian siswa binggung menentukan strategi apa yang harus mereka lakukan untuk menyelesaikan masalah. Untuk membantu siswa menyelesaikan masalah matematis, maka guru harus mampu membimbing siswa untuk benarbenar memahami masalah, membaca masalah yang diberikan dengan baik sehingga paham apa yang dimaksudkan dari soal, memberikan mereka petunjuk yang dapat mengarahkan mereka untuk menemukan solusi. Di dalam satu kelas biasanya terdapat beragam kemampuan siswa, berkemampuan tinggi, sedang dan rendah. Untuk itu, guru perlu menyediakan berbagai jenis dan tingkat bantuan (helps/cognitive scaffolding) yang dapat memfasilitasi kemampuan pemecahan masalah matematis siswa (Nurhayati, Mulyana \& Martadiputra, 2016).

Strategi pembelajaran scaffolding mendorong siswa untuk belajar melalui keterlibatan aktif mereka sendiri. Namun dalam proses pembelajaran siswa mendapat bantuan atau bimbingan dari guru agar lebih terarah sehingga proses pelaksanaan pembelajaran maupun tujuan yang akan dicapai terlaksana dengan baik. Menurut Nurhayati, Mulyana \& Martadiputra (2016), scaffolding berarti memberikan sejumlah besar bantuan kepada seorang anak selama tahap-tahap awal pembelajaran kemudian anak tersebut mengambil alih tangung jawab yang semakin besar segera setelah ia dapat melakukannya. Peran guru dalam strategi scaffolding sangat penting, yaitu guru membantu siswa dalam menuntaskan tugas atau konsep yang awalnya tidak mampu diperoleh secara mandiri. Bantuan tersebut dapat berupa petunjuk, peringatan, dorongan, menguraikan masalah ke dalam langkah-langkah pembelajaran, memberikan contoh ataupun yang lain sehinggga memungkinkan siswa tumbuh mandiri. Menurut Wahyudi (2017) proses scaffolding dapat dimulai dari memotivasi siswa, menjelaskan dan mengerjakan soal. Siswa membutuhkan waktu yang berbeda dalam menerima bantuan. Bantuan yang diberikan guru disesuaikan dengan siswa. Siswa berkemampuan tinggi diberikan tugas belajar mandiri berbantukan buku paket yang relevan. Siswa yang berkemampuan sedang dan rendah diberikan penjelasan mengenai materi pembelajaran untuk membangun pengetahuan awal siswa tentang materi pembelajaran dan siswa dipandu untuk menemukan jawaban dari latihan yang diberikan. Siswa yang yang berkemampuan rendah diberikan perlakuan khusus yaitu pembelajaran ulang ketika mengerjakan latihan. Pada saat mengerjakan latihan siswa berkemampuan rendah dipandu untuk menemukan jawaban latihan lebih banyak dari siswa berkemampuan sedang. Ketika siswa dianggap telah mampu menyelesaikan tugasnya maka guru berhenti memberi bantuan, agar siswa melanjutkan tugasnya secara mandiri (Sutiarso, 2009). Jika kesulitan belajar siswa dapat diatasi dengan baik maka siswa akan dapat meningkatkan kemampuan pemecahan masalah matematika.

Selain strategi pembelajaran, faktor lain yang juga mungkin akan menentukan keberhasilan siswa dalam menerima pelajaran adalah kemampuan awal. Praptiwi dan Handika (2012) menegaskan bahwa kemampuan awal akan mempengaruhi keberhasilan siswa dalam pembelajaran. Kemampuan awal adalah kemampuan yang telah dipunyai oleh siswa sebelum ia 
mengikuti pembelajaran yang akan diberikan (Soemantri, 2016). Kemampuan awal (entry behavior) menggambarkan kesiapan siswa dalam menerima pelajaran yang akan disampaika oleh guru. Kemampuan awal sangat penting diketahui oleh guru sebelum ia memulai pembelajaran. Dengan mengetahui kemampuan awal siswa yang akan diajar, maka mengetahui apakah siswa tersebut telah memiliki pengetahuan prasyarat untuk mengikuti pembelajaran.

Dari uraian tersebut, dapat kita simpulkan bahwa kemampuan pemecahan masalah merupakan kecakapan yang penting dimiliki oleh siswa untuk menghadapi tantangan global di masa mendatang. Namun, dari berbagai survei diketahui bahwa kemampuan pemecahan masalah matematis siswa Indonesia masih tergolong rendah. Oleh sebab itu, perlu dilakukan penanganan khusus demi meningkatkan kemampuan pemecahan masalah matematis siswa. Salah satu strategi yang mungkin dilakukan adalah dengan menggunakan strategi pembelajaran yang dianggap mampu menjadi solusi permasalahan tersebut. Strategi pembelajaran yang mungkin dapat memfasilitasi kemampuan pemecahan masalah adalah strategi scaffolding. Selain strategi pembelajaran, kemampuan awal siswa juga dianggap dapat mempengaruhi kemampuan pemecahan masalah matematis siswa. Jadi, peneliti melakukan penelitian yang bertujuan untuk melihat pengaruh penerapan strategi pembelajaran scaffolding terhadap kemampuan pemecahan masalah ditinjau dari kemampuan awal matematis siswa.

\section{METODE}

Populasi dalam penelitian ini adalah seluruh siswa kelas VIII SMP Negeri 3 Tualang Perawang yang terdiri dari lima kelas yaitu kelas VIII-1, VIII-2, VIII-3, VIII-4, dan VIII-5. Pemilihan sekolah ini berdasarkan pertimbangan permasalahan kemampuan pemecahan masalah matematis siswa, sehingga dipandang sesuai sebagai tempat pelaksanaan penelitian. Penelitian dilakukan dikelas VIII karena pokok bahasan yang dijadikan bahan ajar dalam penelitian ini adalah materi kelas VIII semester 2, sehingga tidak mungkin mengambil populasi kelas VII dan IX. Teknik pengambilan sampel yang digunakan adalah cluster random sampling, yaitu teknik pengambilan sampel secara acak dengan syarat yang diambil homogen (Prasetyo dan Jannah, 2005). Dari seluruh kelas VIII yang homgen kemudian dipilih 2 kelas untuk dijadikan sampel penelitian. Dari dua kelas yang terambil, kelas VIII-1 dijadikan kelas kontrol dan kelas VIII-2 sebagai kelas eksperimen.

Tujuan penelitian ini adalah untuk melihat pengaruh suatu strategi pembelajaran, maka jenis penelitian yang sesuai adalah penelitian eksperimen. Namun dikarenakan banyak faktor yang tidak dapat dikontrol secara penuh, misalnya kesehatan siswa, motivasi belajar dan lain-lain, maka jenis penelitian yang dilakukan adalah eksperimen semu (quasi eksperimen). Di awal penelitian, peneliti melakukan tes kemampuan awal, maka kemampuan pemecahan matematis siswa hanya diukur di akhir pembelajaran dengan melakukan posttes. Jadi, desain yang cocok digunakan dalam penelitian ini adalah nonequivalent posttest-only control group desaign (Mulyatiningsih, 2012). Pada desain ini terdapat dua kelompok yang dipilih secara langsung. kelompok pertama diberi perlakuan (X) dan kelompok yang lain tidak. Kelompok yang diberi perlakuan disebut kelompok eksperimen dan yang tidak diberi perlakuan disebut kelompok kontrol.

Teknik pengumpulan data yang dilakukan adalah dengan tes dan observasi. Terdapat dua jenis tes yang diberikan, yaitu tes kemampuan awal matematis (KAM) dan tes akhir (post-test). Tes KAM diberikan sebelum melakukan pembelajaran menggunakan strategi scaffolding, dan postes dilakukan di akhir pembelajaran. Observasi dilakukan di setiap pertemuan menggunakan lembar observasi. Tujuannya adalah untuk mengontrol pelaksanaan pembelajaran agar sesuai dengan langkah-langkah pembelajaran scaffolding.

Dalam penelitian ini terdapat 3 (tiga) variabel, yaitu strategi pembelajaran scaffolding, kemampuan awal dan kemampuan pemecahan masalah matematis. Teknik analisis menggunakan anova dua arah. Sebelum melakukan pengujian dengan uji anova, maka data yang diperoleh 
haruslah berdistribusi normal. Sebagaimana yang diungkapkan Hartono (2011) menyatakan bahwa pengujian statistik dengan menggunakan teknik Anova dapat dilakukan berdasarkan asumsi bahwa data yang diolah berdistribusi normal.

\section{HASIL}

Sebelum menguraikan hasil uji anova dua jalur, ada baiknya dipaparkan deskripsi hasil tes KAM dan keampuan pemecahan masalah matematis siswa, lihat tabel 1 berikut :

Tabel 1. Deskripsi Hasil Tes KAM dan Kemampuan Pemecahan Masalah Matematis Siswa

\begin{tabular}{ccccc}
\hline Data & Kelas & $\mathbf{N}$ & $\overline{\boldsymbol{x}}$ & SD $_{\mathbf{x}}$ \\
\hline \multirow{2}{*}{ KAM } & Eksperimen & 29 & 54,02 & 21,46 \\
& Kontrol & 29 & 58,72 & 21,79 \\
\multirow{2}{*}{ Posttest } & Eksperimen & 29 & 72,62 & 12,49 \\
& Kontrol & 29 & 67,88 & 14,55 \\
\hline
\end{tabular}

Berdasarkan tabel di atas dapat dilihat bahwa rata-rata kemampuan awal matematis siswa di kedua kelas tidak berbeda jauh, dan dapat dikatakan masih tergolong rendah. Pada hasil postes terdapat perbedaan rata-rata kemampuan pemecahan masalah matematis sebesar 4,78 poin lebih baik di kelas eksperimen. Perbedaan ini akan diujikan lebih lanjut untuk melihat apakah perbedaan tersebut signifikan.

Pengujian menggunakan uji Chi kuadrat menunjukkan bahwa rata-rata nilai KAM dan kemampuan pemecahan masalah matematis siswa berdistribusi normal. Hasil uji homogenitas menggunakan uji-F menunjukkan data yang diperoleh homogen. Selanjutnya dilakukan uji anova dua arah dengan taraf signifikansi $5 \%$, untuk memastikan signifikansi perbedaan rata-rata kemampuan pemecahan masalah matematis di kedua kelas. Berikut hasil uji anova dua arah yang diperoleh :

Tabel 2. Hasil Uji Anova Dua Arah

\begin{tabular}{lccccc}
\hline \multicolumn{1}{c}{ Sumber Varian } & JK & K & RJK & $\mathbf{F}_{\text {Hitung }}$ & $\mathbf{F}_{\text {Tabel }}$ \\
\hline Antar A (Strategi) & 408,897 & 1 & 408,897 & 4,772 & 4,03 \\
Antar B (KAM) & 5363,165 & 2 & 2682,58 & 31,297 & 3,18 \\
Interksi A × B & 265,82 & 2 & 132,91 & 1,552 & 3,18 \\
Dalam & 4455,498 & 2 & 85,683 & - & - \\
Total & 10493,38 & 7 & - & - & - \\
\hline
\end{tabular}

Berdasarkan tabel hasil perhitungan uji anova dua arah maka dapat disimpulkan:

a. Nilai $\mathrm{F}(\mathrm{A})_{\text {hitung }}>\mathrm{F}(\mathrm{A})_{\text {tabel, }}$, atau $4,772>4,03$, maka $\mathrm{H}_{0}$ ditolak. Artinya, pada taraf kepercayaan $5 \%$ terdapat perbedaan kemampuan pemecahan masalah matematis siswa yang mengikuti pembelajaran scaffolding dengan siswa yang mengikuti pembelajaran konvensional.

b. Nilai $\mathrm{F}(\mathrm{B})_{\text {hitung }}>\mathrm{F}(\mathrm{B})_{\text {tabel }}$ atau $31,297>3,18$ maka $\mathrm{H}_{0}$ di tolak. Artinya, pada taraf kepercayaan 5\% terdapat perbedaan kemampuan pemecahan masalah matematis antara siswa dengan kemampuan awal tinggi, sedang dan rendah.

c. Nilai $\mathrm{F}(\mathrm{A} \times \mathrm{B})_{\text {hitung }}<\mathrm{F}(\mathrm{A} \times \mathrm{B})_{\text {tabel }}$, atau 1,552 $<3,18$ maka $\mathrm{H}_{0}$ di terima. Artinya, pada taraf kepercayaan 5\% tidak terdapat interaksi penerapan strategi pembelajaran scaffolding dengan kemampuan awal matematika terhadap kemampuan pemecahan masalah matematis siswa. 


\section{PEMBAHASAN}

Berdasarkan hasil analisis data yang dipaparkan sebelumnya, dapat dilihat bahwa terdapat perbedaan kemampuan pemecahan masalah matematis antara siswa yang mengikuti strategi pembelajaran scaffolding dengan siswa yang mengikuti pembelajaran konvensional berdasarkan kemampuan awal tinggi, sedang dan rendah pada siswa. Lebih lengkapnya hasil temuan bahwa pada taraf kepercayaan 5\% terdapat perbedaan yang signifikan antara kemampuan pemecahan masalah matematis siswa yang mengikuti pembelajaran scaffolding dengan siswa yang mengikuti pembelajaran konvensional. Hasil penelitian ini mengkonfirmasi hasil penelitian yang dilakukan oleh Syar, Sudia dan Sahidin (2015), Ashari dan Fitriani (2016), Nurhayati, Mulyana dan Martadiputra (2016). Penelitian tindakan kelas (PTK) yang dilakukan oleh Syar, Sudia dan Sahidin (2015) di SMP 5 Kendari tersebut menunjukkan peningkatan kemampuan pemecahan masalah matematis siswa yang diberikan pembelajaran scaffolding. Ashari dan Fitriani (2016) menyatakan bahwa kemampuan dalam membuktikan teorema-teorema dapat berkembang melalui pembelajaran scaffolding. Nurhayati, Mulyana dan Martadiputra (2016) menyimpulkan bahwa kemampuan pemecahan masalah matematis siswa yang memperoleh pembelajaran yang menerapkan scaffolding termasuk kategori tinggi.

Menurut Qomar dan Riyadi (2016) pemberian scaffolding akan mendorong siswa mengembangkan inisiatif, motivasi dan sumber dayanya. Pemberian scaffolding membantu siswa mengembangkan pemahaman atas pengetahuan dan proses yang baru. Dalam penerapan pembelajaran scaffolding, siswa diarahkan untuk menyelesaikan persoalan yang diberikan di dalam kelompok. Pembelajaran dimulai dengan memberikan motivasi kepada siswa, petunjuk, peringatan, dorongan, menguraikan masalah ke dalam langkah-langkah pembelajaran, memberikan contoh, mengerjakan soal. Siswa diberikan bantuan sesuai dengan kemampuannya masing-masing. Mereka juga diajak untuk berbagi pengetahuan di dalam kelompok, bekerjasama dalam menyelesaikan persoalan yang diberikan dengan bantuan dari guru. Kerja sama di dalam kelompok, motivasi serta bantuan dari guru inilah yang diyakini dapat mendorong siswa untuk mengatasi kesulitan mereka dalam memecahkan masalah. Jika kesulitan sudah dapat diselesaikan, tentunya kemampuan pemecahan masalah matematis siswa akan berkembang.

Hasil penelitian juga menunjukkan bahwa terdapat perbedaan rata-rata kemampuan pemecahan masalah matematis siswa yang blajar dengan strategi pembelajaran scaffolding dibanding siswa yang memperoleh pembelajaran konvensional ditinjau dari kemmapuan awal matematis siswa. Artinya, baik siswa yang memiliki kemampuan awal rendah, sedang ataupun tinggi dapat mengikuti pembelajaran scaffolding dengan baik. Terakhir, tidak terdapat interaksi penerapan strategi pembelajaran scaffolding dengan kemampuan awal matematis terhadap kemampuan pemecahan masalah matematis siswa. Dengan demikian, peningkatan kemampuan pemecahan masalah matematis siswa karena strategi pembelajaran scaffolding dan tidak dipengaruhi oleh kemampuan awal matematika siswa. Selain itu, kemampuan pemecahan masalah matematis siswa yang memiliki kemampuan awal tinggi, kemampuan awal sedang dan kemampuan awal rendah tidak dipengaruhi oleh strategi pembelajaran scaffolding.

Selanjutnya, peneliti dapat merekomendasikan strategi pembelajaran scaffolding dapat dijadikan salah satu alternatif strategi pembelajaran pada mata pelajaran matematika. Penelitian ini dapat dilanjutkan dengan mengembangkan penerapan strategi pembelajaran scaffolding seperti mengkombinasikannya dengan pendekatan saintifik. 


\section{DAFTAR PUSTAKA}

Ashari. N.W dan Fitriani. S. (2016). Implementasi Strategi Pembelajaran Scaffolding melalui Lesson Study pada Mata Kuliah Analisis Real. Jurnal Matematika dan Pendidikan Matematika, 1(1), 23-36.

Dit. PSMA. (2017). Implementasi Pengembangan Kecakapan AbAd 21 dalam Perencanaan Pelaksanaan Pembelajaran (RPP). Jakarta : Ditjen Pendidikan Dasar dan Menengah.

Hartono. (2011). Metodologi Penelitian. Pekanbaru: Zanafa Publishig.

Mulyatiningsih. E. (2012). Metode Penelitian Terapan Bidang Pendidikan. Bandung: Alfabeta.

Nurhayati, E, Mulyana, T, Martadiputra, B.A.P. (2016). Penerapan Scaffolding untuk Pencapaian Kemampuan Pemecahan Masalah Matematis. Jurnal Penelitian dan Pengajaran Matematika, . 2 (2), 107-112.

NCTM. (2000). Principles and Standards for School Mathematics. Virginia : NCTM Inc.

OECD. (2018). Pisa 2015 Result on Focus. Tersedia : www.oecd.org/pisa.

Peraturan Menteri Pendidikan dan Kebudayaan. (2016). Standar Isi Pendidikan Dasar dan Menengah. Jakarta : Kemendikbud.

Prasetyo. B dan Jannah.L.M. (2005). Metode Penelitian Kuantitatif. Jakarta: Grafindo Persada

Praptiwi dan Handhika, J. Efektivitas Metode Kooperatif Tipe GI dan STAD ditinjau dari Kemampuan Awal.Jurnal Penelitian Pembelajaran Fisika, 3(1) : 41-50.

Qomar, K dan Riyadi, S. (2016). Bentuk Scafflding dalam Pembelajaran Matematika menggunakan Aplikasi Berbasis Teks. Prosiding Seminar Nasional Pendidikan Matematika Universitas Kanjuruban Malang, Volume 1, 2016, 301-305.

Sumantri, M.S. (2016). Strategi Pembelajaan. Jakarta: PT Raja Grafindo Persada.

Sutiarso, S. (2009). Scaffolding dalam Pembelajaran Matematika. Prosiding Seminar Nasional Penelitian, Pendidikan dan Penerapan MIPA, Fakultas MIPA,Universitas Negeri Yogyakarta.

Syar, R, Sudia, M dan Sahidin, L.(2015). Meningkatkan Kemampuan Pemecahan Masalah Matematika melalui Stategi Pembelajaran Scaffolding Siswa Kelas VIII-D SMP Negeri 5 Kendari. Jurnal Penelitian Pendidikan Matematika, 3(2), 78-90.

Tambychik, T, Meerah S.M. (2010). Students' Difficulties in Mathematics Problem : What do They Say?. Procedia - Social and Behavioral Sciences : 142-151.

Wahyudi. (2017). Scaffolding sesuai Gaya Belajar sebagai Upaya Meningkatkan Kemampuan Berpikir Matematis Siswa. Premiere Educantum : Jurnal Pendidikan Dasar Pembelajaran, 7(2), 144-157. 